\title{
Recent advances in understanding assembly of the primary cilium membrane
}

\author{
Saurabh Shakya ${ }^{1} \quad$ Christopher J. Westlake (iD ${ }^{1 *}$ \\ ${ }^{1}$ Center for Cancer Research, National Cancer Institute, National Institutes of Health, Frederick, Laboratory of Cellular and Developmental Signaling, Frederick, \\ MD 21702, USA
}

\begin{abstract}
Ciliogenesis describes the assembly of cilia in interphase cells. Several hundred proteins have been linked to ciliogenesis, which proceeds through a highly coordinated multistage process at the distal end of centrioles requiring membranes. In this short review, we focus on recently reported insights into the biogenesis of the primary cilium membrane and its association with other ciliogenic processes in the intracellular ciliogenesis pathway.
\end{abstract}

Keywords

Ciliogenesis, primary cilium, Rab, membrane trafficking, ciliopathy

\section{Peer Review}

The peer reviewers who approve this article are:

1. Lotte B Pederson, Department of Biology, University of Copenhagen, Copenhagen Ø, Denmark Competing interests: No competing interests were disclosed.

2. Duarte C Barral, CEDOC, NOVA Medical School, Faculdade de Ciências Médicas, Universidade NOVA de Lisboa, Lisbon, Portugal

Competing interests: No competing interests were disclosed. 
*Corresponding author: Christopher J. Westlake (chris.westlake@nih.gov)

Competing interests: The authors declare that they have no competing interests.

Grant information: SS and CJW are supported by federal funds from the National Cancer Institute, National Institutes of Health, under contract HHSN261200800001E. The content of this publication does not necessarily reflect the views or policies of the US Department of Health and Human Services, nor does mention of trade names, commercial products, or organizations imply endorsement by the US Government.

The funders had no role in study design, data collection and analysis, decision to publish, or preparation of the manuscript.

Copyright: (c) 2021 Westlake CJ et al. This is an open access article distributed under the terms of the Creative Commons Attribution License, which permits unrestricted use, distribution, and reproduction in any medium, provided the original work is properly cited.

How to cite this article: Shakya S and Westlake CJ. Recent advances in understanding assembly of the primary cilium membrane. Faculty Reviews 2021 10:(16) https://doi.org/10.12703/r/10-16

Published: 22 Feb 2021, Faculty Reviews 10:(16) https://doi.org/10.12703/r/10-16 


\section{Introduction}

Human cells typically have a single immotile primary cilium or one or more motile cilia. The primary cilium functions in multiple signal transduction pathways needed for normal development and tissue homeostasis ${ }^{1,2}$. Defects in the function of this organelle cause genetic disease, referred to as ciliopathy.

The primary cilium develops from the mother centriole (MC) and is structurally comprised of a microtubule-based axoneme surrounded by a ciliary membrane, which serves as the chief signaling hub for the organelle. A transition zone (TZ) at the cilium base acts as a molecular gate to regulate entrance and exit of proteins and lipids ${ }^{3,4}$. Notably, the majority of ciliopathy-linked proteins localize to the $\mathrm{TZ}^{2,5}$. Intraflagellar transport (IFT) proteins were the first proteins shown to function in ciliogenesis, and both IFT-A and IFT-B complexes regulate anterograde and retrograde transport along the axoneme $^{6-10}$. Although many other proteins have been shown to be important for ciliogenesis, we still have only a very basic understanding of the mechanisms involved in this process.

\section{Ciliogenesis mechanisms}

The assembly of the cilium is thought to occur by two mechanisms: an extracellular pathway and an intracellular pathway. Polarized epithelial cells use the extracellular pathway, whereas fibroblasts and mesenchymal cells follow the intracellular scheme $^{11,12}$. In both pathways, docking of cellular membranes to the distal appendages (DAs) on the MC (Figure 1) triggers the removal of proteins from the MC, referred to as MC uncapping, needed for axoneme assembly ${ }^{13}$. This centriole cap controls the elongation of these microtubule triplet-based structures ${ }^{14}$. In the extracellular ciliogenesis pathway, the MC docks directly to the plasma membrane (PM) through distal appendage proteins (DAPs) on the DAs ${ }^{15}$, although there are many outstanding questions about the initiation mechanisms involved in this process. Most recently, it was suggested that

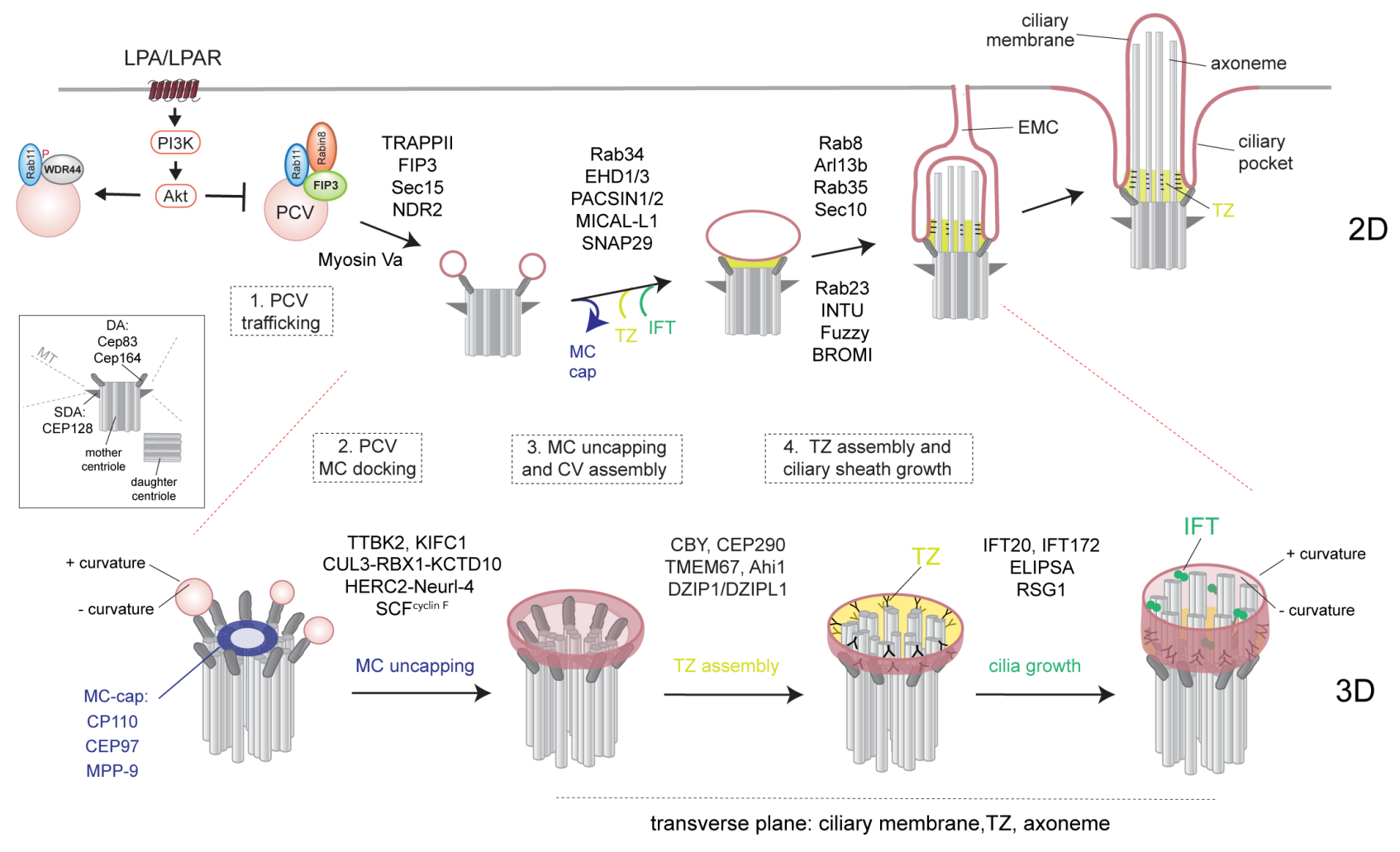

Figure 1. Membrane trafficking regulation of primary cilium assembly in intracellular pathway. Membrane trafficking regulation of ciliogenesis stages illustrated in two dimensions (2D) (top) and three dimensions (3D) (bottom). Ciliogenic factors linked to membrane trafficking are shown for ciliogenesis stages associated with (1) mitogen signaling regulation of preciliary vesicle (PCV) trafficking to the mother centriole (MC), (2) docking of PCVs to the MC mediated by subdistal appendage (SDA) and distal appendage (DA) proteins (inset), (3) assembly of the ciliary vesicle (CV) from PCVs and associations with the ubiquitin degradation of the MC cap, and (4) coordination of ciliary sheath membrane growth and transition zone (TZ) and axoneme assembly. The developing intracellular cilium can emerge from the cell surface via the formation of an extracellular membrane channel (EMC) which develops from the ciliary membrane to plasma membrane (gray line). Pink membranes show the developing ciliary membrane and ciliary pocket, and + and - curvature indicates membrane surface shape. IFT, intraflagellar transport; MT, microtubule. 
the cytokinesis midbody remnant directs MC docking to the $\mathrm{PM}^{16}$. In contrast, in the intracellular ciliogenesis pathway, the cilium is assembled at least partially in the cytoplasm and involves the trafficking of membrane vesicles from the endocytic recycling compartment (ERC) and the Golgi to the $\mathrm{MC}^{15,17-19}$ (Figure 1). Preciliary vesicles (PCVs) dock to DAPs, where they have been referred to as distal appendage vesicles (DAVs), and subsequently fuse to form a larger ciliary vesicle $(\mathrm{CV})$ covering the distal end of the $\mathrm{MC}^{15,18,20,21}$. This process triggers $\mathrm{MC}$ uncapping followed by the growth of the axoneme surrounded by a double-membrane sheath that develops from the $\mathrm{CV}$.

\section{Ciliogenesis initiation and the Rab11-Rab8 cascade}

The earliest mechanistic evidence showing membrane trafficking regulator associations with the intracellular pathway came from the observation that a Rab11-Rab8 cascade functions in ciliogenesis ${ }^{18,22-24}$. Rabs are members of the Ras superfamily of small GTPases and are master regulators of membrane trafficking important in the biogenesis, transport, tethering, and fusion of membranous structures in the cell ${ }^{25}$. Rab11 organizes the trafficking of PCVs from the ERC and transports Rabin8, a Rab8 guanine nucleotide exchange factor (GEF), to the MC in order to activate Rab8 to grow the ciliary membrane at the $\mathrm{CV}$ stage ${ }^{18,20}$. This preciliary trafficking process occurs within minutes of cues for cells to ciliate, suggesting that this is a key step in ciliogenesis initiation ${ }^{18}$. Recently, we showed that Rabin8 PCV-dependent trafficking and ciliogenesis initiation are negatively regulated by lysophosphatidic acid (LPA)/LPA receptor 1 (LPAR1)-dependent activation of the PI3K-Akt signaling pathway in cultured cells $^{26}$. Akt phosphorylates the Rab11 effector WDR44 and stabilizes its binding to Rab11, thus preventing the formation of an effector complex between Rab11 and FIP3 needed to traffic Rabin8-containing PCVs to the MC.

\section{Docking preciliary vesicles to the mother centriole}

How PCVs are trafficked by the cytoskeleton to the MC DAs remains unclear, although the Golgi-associated motors dynein-2, Myosin Va, and kinesin-14 (KIFC1) have been linked to ciliogenesis ${ }^{19,21,27-29}$. Preciliary trafficking of Rabin8-containing PCVs requires microtubules ${ }^{18}$, yet microtubules are likely not anchored to DAs but are observed on more proximal subdistal appendages (SDAs) on the $\mathrm{MC}^{30}$ (Figure 1). This raises the possibility that PCVs are first trafficked to the SDAs and then shuttled to the DAs. Indeed, the SDA protein CEP128 has been shown to mediate Rab11 association with the $\mathrm{MC}^{31}$ while Rabin8 can interact with the DAP CEP164 ${ }^{32}$. PCV transport from SDAs to DAs could be assisted by large-molecular-weight membrane trafficking regulator complexes, including TRAPPII and the exocyst, both of which are required for ciliogenesis and interact with Rabin8 through their respective components TRAPPC14 and Sec15 $18,33,34$. This idea is supported by the observation that TRAPPC14 interacts with the DAPs CEP83 and FBF1 ${ }^{33}$. The more proximal DA position of CEP83, closer to the SDA, could enable a "hand-off" of PCVs to the distally localized DAP CEP164, a presumed anchor point for the ciliary membrane ${ }^{35}$.
Pericentriolar PCV transport to the MC has also been recently reported to be regulated by the motor protein Myosin $\mathrm{Va}^{21}$. This mechanism is independent of Rabin8 preciliary trafficking, suggesting that more than one type of PCV may be involved in cilium assembly ${ }^{33}$. Consistent with this idea, several other Rabs have been linked to ciliogenesis (Rab10, -23, -29, -34 , and -35), although their precise functions are poorly understood $^{24,36-41}$. Interestingly, in contrast to Rab8, its closest homolog Rab10 was recently shown to block ciliogenesis through a phosphorylation-dependent process involving the shared effector RILPL1, which localizes to the MC and prevents ciliogenesis ${ }^{42}$. These findings differ from an earlier study showing that Rab8 and Rab10 have overlapping ciliogenesis functions ${ }^{41}$. Interestingly, both Rabs are activated by Rabin $8^{43,44}$, suggesting that regulation of its GEF function could be important for Rab8 and Rab10 opposing ciliogenesis roles.

\section{Ciliary vesicle assembly}

Following docking of PCVs to the MC, the Rab11- and Rab8-associated endosomal membrane trafficking regulators EHD1 and EHD3, along with their binding partners MICAL-L1 and the F-BAR membrane-shaping protein PACSIN1 and -2, function in the assembly of the $\mathrm{CV}^{20,45-47}$. F-BAR-containing proteins are involved in sensing or establishing membrane curvature or both ${ }^{48}$. EHD proteins may also influence membrane shape directly or indirectly by recruiting PACSINS to membranes and assist with membrane fusion ${ }^{47,49}$. EHD1 recruits both PACSINs and SNAP29, a SNARE membrane fusion regulator ${ }^{20}$, to DAVs, while Rab34 was recently reported to mediate EHD1 association with MC-associated ciliogenic membranes ${ }^{36}$. Together, these observations support a model wherein DAVs fuse to form the $\mathrm{CV}$, a process that appears to require membrane shaping.

\section{Membrane trafficking regulator links to mother centriole uncapping}

Ciliogenic EHD and PACSIN proteins and MICAL-L1 are required for MC uncapping, suggesting that this process is dependent on CV assembly ${ }^{20,45-47}$, although inexplicitly Rab34 is dispensable for MC cap removal ${ }^{36}$. The MC cap is comprised of three proteins: CP110, CEP97, and M-phase phosphoprotein 9 (MPP9) ${ }^{14,50}$. MC uncapping involves several proteasomal deg-

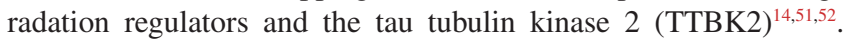
Whereas some of these factors localize to the MC, others are recruited upon initiation of ciliogenesis, suggestive of directed transport mechanisms. TTBK2 recruitment to the MC depends on the motor $\mathrm{KIFC}^{19}$ and changes in PtdIns(4)P levels ${ }^{53}$, a lipid enriched in the ERC and Golgi-derived vesicles ${ }^{54,55}$. New insights into the initiation of MC uncapping have recently emerged from characterizations of MPP9 $^{50}$. The motor KIF24 maintains MPP9 at the MC under non-ciliating conditions, and following ciliogenesis initiation, TTBK2 is recruited to the MC where it phosphorylates MPP9 at $\mathrm{Ser}^{629}$, resulting in its removal by an unknown mechanism. MPP9 loss from the MC cap could trigger a cascade whereby CEP97 and CP110 are degraded. The E3 ligase complex CUL3-RBX1-KCTD10 degrades $\mathrm{CEP} 97^{52}$, and CP110 degradation has been linked to the ubiquitin ligases HERC2 and SCF cyclinF14,56,57. Interestingly, 
the HERC2 cofactor Neurl-4 translocates from the daughter centriole to MC during ciliogenesis ${ }^{58}$. Thus, it seems plausible that PCVs could be involved in trafficking this and other factors needed for MC uncapping.

\section{Transition zone and ciliary membrane assembly}

$\mathrm{TZ}$ protein recruitment to the $\mathrm{MC}$ also coincides with the DAV-to-CV assembly stage, suggesting a role for PCVs in transporting $\mathrm{TZ}$ factors ${ }^{20,45}$. Interestingly, the $\mathrm{TZ}$ protein Chibby (CBY) stabilizes Rabin8 and CEP164 associations ${ }^{59}$, suggesting that this $\mathrm{TZ}$ protein could affect PCV docking to DAPs or regulate downstream Rab8 activation or both. Similarly, the TZ protein CEP290 is important for recruiting Rab8 to the developing cilium ${ }^{60}$. Importantly, mutation or ablation of CBY and CEP290 as well as other TZ proteins (TMEM67, Ahi1, and DZIP1/DZIPL1) disrupts ciliogenesis progression at the CV stage $^{59-66}$. Based on these findings, it seems likely that a fully functional $\mathrm{TZ}$ is established as the $\mathrm{CV}$ develops into the ciliary sheath membrane. Structurally, the TZ has a Y-shape connecting the ciliary membrane to the microtubule doublets of the axoneme ${ }^{67,68}$. Thus, predicted transmembrane domain-containing TZ proteins such as TMEM67, TMEM216, TMEM231, and TMEM237 could link the ciliary membrane to the Y-shaped structures $^{3,69-73}$. Moreover, given TMEM67 requirements at the $\mathrm{CV}$ stage, it, along with other TZ proteins, may be important for coordinating $\mathrm{TZ}$ and ciliary membrane assembly.

Establishing a functional TZ early in ciliogenesis could also be important for reorganizing the $\mathrm{CV}$, from a spherical-like structure with a positive-curved cytoplasmic outward-facing membrane, into the ciliary sheath, with both positive and negative membrane curvature (Figure 1). The membrane opposed to the axoneme in the ciliary sheath and mature cilium also has negative curvature. Given the molecular gating function of the TZ, it could therefore help partition proteins and lipids in order to reorganize the membrane of the $\mathrm{CV}$ into the ciliary sheath. For example, the positive curvature-associated membrane-shaping factors PACSIN and EHD proteins would be predicted to interfere with establishing negative-membrane curvature at post-CV stages. Consistent with this idea, PACSIN1 and -2 and EHD1 and -3 are not detected in the mature cilium but are observed on the positively curved cytoplasmic surface of the ciliary pocket membrane ${ }^{20,45}$. Interestingly, the $\mathrm{TZ}$ protein FAM92 has an undefined BAR domain which could be important for establishing membrane curvature during ciliogenesis ${ }^{74}$. Further investigation of membrane-shaping mechanisms involved in CV-to-ciliary sheath transition is needed to better understand these processes. Clues to how membrane-shaping regulators affect primary cilium assembly may be found in studies of worm sensory cilia which can undergo dramatic membrane remodelling ${ }^{75,76}$.

\section{Coordinating growth of the ciliary membrane and the axoneme}

The growth of the ciliary membrane and the axoneme microtubule doublets appears to be tightly coupled. Disruption of regulators of membrane trafficking and microtubule assembly blocks ciliogenesis at the CV stage or causes shortened cilia $^{5,20,77,78}$. IFT proteins play a critical role in coordinating cilium axoneme growth via interactions with molecular motors and ciliary cargos ${ }^{79,80}$. IFT20 localizes to the Golgi ${ }^{17}$ and is recruited to the MC between the DAV and CV stages $^{20}$ via the motor KIFC $1^{19}$, suggesting that PCVs could be involved in the delivery of IFT20 to the MC. Interestingly, in Chlamydomonas, IFT-associated membrane vesicles were discovered near the base of the flagella and also contain axonemal components, suggesting that ciliogenic associations between ciliary membranes and axoneme occur outside of the cilium ${ }^{81}$. Finally, a more direct function of IFT on membrane trafficking was proposed for IFT172, which was shown to shape lipid membranes in vitro $^{82}$.

Live cell imaging studies demonstrated that Rab8 accumulates in the growing cilium, supporting a role in the extension of the ciliary membrane ${ }^{18,20}$. Consistent with this idea, reduced PCV trafficking of Rabin8, regulated by the kinase NDR2, and ciliary accumulation of Rab8 are observed following the growth of the primary cilium ${ }^{18,34}$. Rab8- and IFT-coordinated functioning in cilium growth could be coupled by ELIPSA, which interacts with IFT20 and the membrane trafficking and ciliogenesis regulator Rabaptin5, which in turn interacts with Rab8 ${ }^{83}$. Interestingly, IFT20 and Rab8 membrane trafficking regulation associations are further supported by studies in $\mathrm{T}$ cells, which despite lacking cilia require both proteins to regulate vesicular receptor recycling important for immune synapse function $^{84,85}$.

Several other membrane trafficking regulators have also been linked to IFT and the extension of the cilium. Like Rab8, the exocyst regulator Sec10 accumulates in the cilium and associates with IFT proteins ${ }^{86,87}$. Another Ras superfamily member, Arl13b, functions in ciliogenesis and interacts with the IFT-B complex and mediates IFT-A retrograde transport on the axoneme ${ }^{88}$. Notably, Arl13b localizes to the ciliary membrane after the CV stage and has also been linked to exocyst ciliogenic function $^{89,90}$, although the precise role of these proteins in cilium growth remains elusive. Rab35 was also recently reported to regulate cilium length by affecting Arl13b and lipid levels in the cilium ${ }^{37}$. Thus, Arl13b may serve as a bridge between IFT and membrane trafficking regulators in coordinating growth of the axoneme and the ciliary membrane. Rab23 has also been linked to IFT and ciliary growth ${ }^{91}$. Evidence for Rab23 requirements in ciliogenesis and cilium maintenance has also come from studies using Rab23 dominant-negative expression $^{39}$ and investigation of its GTPase regulation by the GTPase-activating protein (GAP) Evi5L ${ }^{24}$ and the GEF complex Inturned (INTU) and Fuzzy, components of the CPLANE complex important for establishing planar cell polarity ${ }^{91}$. Interestingly, INTU and Fuzzy activate Rab23 for post-CV ciliogenic stages ${ }^{91}$ and INTU is known to modulate IFT ciliary trafficking $^{78,92}$. Moreover, INTU interacts with another GTPase, RSG1, which is needed for assembly of the axoneme ${ }^{78}$. Together these observations point to multiple mechanisms whereby IFT couples axoneme and ciliary membrane growth in 
coordination with Rabs and other membrane trafficking regulators. These mechanisms are also likely important for IFT-dependent regulation of membrane cargo transport needed for ciliary signaling ${ }^{79,80}$.

Interestingly, very few reports have described the uncoupling of the growth of the primary cilium membrane and axoneme ${ }^{66}$. Ultrastructure analysis of fibroblasts from Joubert syndrome ciliopathy patients with CEP290 mutations displayed intracellular axonemes lacking ciliary membranes, yet DAVs appeared to be docked to the $\mathrm{MC}^{66}$. In contrast, depletion of the putative Rab-GAP Broad-minded (BROMI) showed detached and expanded ciliary membranes on one side of a seemingly normal axoneme in the zebrafish pronephros, although the target Rab has not been identified ${ }^{93}$.

Fusion of the intracellular cilium with the cell surface How the intracellular developing cilium emerges from the cell is another question that was recently investigated ${ }^{45}$. We discovered that the cilium can emerge from the cytoplasm via the formation of tubulovesicles organized from the positively curved surfaces of the CV and ciliary sheath membranes. These tubulovesicle structures are guided to the PM on microtubules, and upon fusion of these discrete membranes, an extracellular membrane channel (EMC) that exposes the ciliary membrane to the extracellular environment is formed. EHD and PACSIN proteins help reorganize these tubulovesicles ${ }^{20,45}$, and presumably Rabs, SNAREs, and molecular motors also function in this process as well. This study also showed Rab8 on these tubulovesicles, suggesting that factors needed for ciliogenesis could be delivered to the developing cilium from these structures, possibly originating from the PM. Thus, the intracellular and extracellular ciliogenesis pathways could use a similar mechanism for delivering ciliogenic cargo to the $\mathrm{MC}$ following docking to the PM.

\section{Conclusions}

In this review, we examined new insights and models for membrane trafficking function in mediating discrete steps important for cilium assembly. Other membrane trafficking regulators have also recently been linked to ciliogenesis and ciliary trafficking, including the HOPS, ESCRT, and BLOC-1 complexes $^{94-96}$. Thus, future studies examining these and other trafficking factors are important to address outstanding questions posed in this review, in particular relating to how PCVs specifically traffic and dock to the MC and how they organize to become the unique ciliary membrane in close coordination with the assembly of the ciliary TZ and axoneme. Although we did not focus on disease associations with membrane trafficking regulators, it is important to note that mutations in the membrane trafficking regulators are associated with ciliopathy: Arl13b (Joubert syndrome) ${ }^{97}$, Rab23 (Carpenter syndrome) ${ }^{98}$, and the exocyst subunits Exo84 (Joubert syndrome) ${ }^{99}$ and Sec8 (Meckel-Gruber syndrome) ${ }^{100}$. Thus, the investigation of fundamental ciliogenesis membrane trafficking process will undoubtedly enhance our understanding of cilia-related human disease.

\section{Abbreviations}

CBY, Chibby; CV, ciliary vesicle; DA, distal appendage; DAP, distal appendage protein; DAV, distal appendage vesicle; ERC, endocytic recycling compartment; GAP, GTPase-activating protein; GEF, guanine nucleotide exchange factor; IFT, intraflagellar transport; INTU, inturned; KIFC1, kinesin-14; LPA, lysophosphatidic acid; MC, mother centriole; MPP9, M-phase phosphoprotein 9; PCV, preciliary vesicle; PM, plasma membrane; SDA, subdistal appendage; TTBK2, tau tubulin kinase 2; $\mathrm{TZ}$, transition zone

\section{Authors' contributions}

SS and CJW contributed to conceptualization and manuscript writing and editing.

\section{Acknowledgments}

The authors are grateful to Christine Insinna, Huijie Zhao, and Quanlong $\mathrm{Lu}$ (Center for Cancer Research, National Cancer Institute, National Institutes of Health, Frederick, Laboratory of Cellular and Developmental Signaling, Frederick) for critical reading of the manuscript.
1. Goetz SC, Anderson KV: The primary cilium: A signalling centre during vertebrate development. Nat Rev Genet. 2010; 11(5): 331-44. PubMed Abstract | Publisher Full Text | Free Full Text

2. Reiter JF, Leroux MR: Genes and molecular pathways underpinning ciliopathies. Nat Rev Mol Cell Biol. 2017; 18(9): 533-47. PubMed Abstract | Publisher Full Text | Free Full Text

3. Gonçalves J, Pelletier L: The Ciliary Transition Zone: Finding the Pieces and Assembling the Gate. Mol Cells. 2017; 40(4): 243-53. PubMed Abstract | Publisher Full Text | Free Full Text

4. Garcia-Gonzalo FR, Reiter JF: Open Sesame: How Transition Fibers and the Transition Zone Control Ciliary Composition. Cold Spring Harb Perspect Biol. 2017; 9(2): a028134.

PubMed Abstract | Publisher Full Text | Free Full Text
5. Malicki JJ, Johnson CA: The Cilium: Cellular Antenna and Central Processing Unit. Trends Cell Biol. 2017; 27(2): 126-40. PubMed Abstract | Publisher Full Text | Free Full Text

6. Yang $\mathrm{H}$, Huang $\mathrm{K}$ : Dissecting the Vesicular Trafficking Function of IFT Subunits. Front Cell Dev Biol. 2019; 7: 352.

PubMed Abstract | Publisher Full Text | Free Full Text

7. Lechtreck KF: IFT-Cargo Interactions and Protein Transport in Cilia. Trends Biochem Sci. 2015; 40(12): 765-78. PubMed Abstract | Publisher Full Text | Free Full Text

8. Yang N, Li L, Eguether T, et al.: Intraflagellar transport 27 is essential for hedgehog signaling but dispensable for ciliogenesis during hair follicle morphogenesis. Development. 2015; 142(16): 2860. PubMed Abstract | Publisher Full Text | Free Full Text 
9. Mukhopadhyay S, Wen X, Chih B, et al:: TULP3 bridges the IFT-A complex and membrane phosphoinositides to promote trafficking of $G$ protein-coupled receptors into primary cilia. Genes Dev. 2010; 24(19): 2180-93. PubMed Abstract | Publisher Full Text | Free Full Text

10. Kozminski KG, Johnson KA, Forscher P, et al:: A motility in the eukaryotic flagellum unrelated to flagellar beating. Proc Natl Acad Sci U S A. 1993; 90(12): 5519-23.

PubMed Abstract | Publisher Full Text | Free Full Text

11. Molla-Herman A, Ghossoub R, Blisnick T, et al.: The ciliary pocket: An endocytic membrane domain at the base of primary and motile cilia. J Cell Sci. 2010; 123(Pt 10): 1785-95.

PubMed Abstract | Publisher Full Text

12. Sorokin $\mathrm{S}$ : Centrioles and the formation of rudimentary cilia by fibroblasts and smooth muscle cells. J Cell Biol. 1962; 15(2): 363-77. PubMed Abstract | Publisher Full Text | Free Full Text

13. Wang $\mathrm{L}$, Dynlacht $\mathrm{BD}$, et al:: The regulation of cilium assembly and disassembly in development and disease. Development. 2018; 145(18): dev151407. PubMed Abstract | Publisher Full Text | Free Full Text

14. Spektor A, Tsang WY, Khoo D, et al.: Cep97 and CP110 suppress a cilia assembly program. Cell. 2007; 130(4): 678-90.

PubMed Abstract | Publisher Full Text | Faculty Opinions Recommendation

15. Sorokin SP: Reconstructions of centriole formation and ciliogenesis in mammalian lungs. J Cell Sci. 1968; 3(2): 207-30.

PubMed Abstract

16. Bernabé-Rubio M, Andrés G, Casares-Arias J, et al:: Novel role for the midbody in primary ciliogenesis by polarized epithelial cells. J Cell Biol. 2016; 214(3): $259-73$.

PubMed Abstract | Publisher Full Text | Free Full Text

17. Follit JA, Tuft RA, Fogarty KE, et al:: The intraflagellar transport protein IFT20 is associated with the Golgi complex and is required for cilia assembly. Mol Biol Cell. 2006; 17(9): 3781-92

PubMed Abstract | Publisher Full Text | Free Full Text

18. Westlake CJ, Baye LM, Nachury MV, et al:: Primary cilia membrane assembly is initiated by Rab11 and transport protein particle II (TRAPPII) complexdependent trafficking of Rabin8 to the centrosome. Proc Natl Acad Sci U S A. 2011; 108(7): 2759-64.

PubMed Abstract | Publisher Full Text | Free Full Text

19. 2 Lee S-H, Joo K, Jung EJ, et al.: Export of membrane proteins from the Golgi complex to the primary cilium requires the kinesin motor, KIFC1. FASEB J. 2018; 32(2): 957-68.

PubMed Abstract | Publisher Full Text | Faculty Opinions Recommendation

20. Lu Q, Insinna C, Ott C, et al.: Early steps in primary cilium assembly require EHD1/EHD3-dependent ciliary vesicle formation. Nat Cell Biol. 2015; 17(3): $228-40$

PubMed Abstract | Publisher Full Text | Free Full Text

21. Wu CT, Chen HY, Tang TK: Myosin-Va is required for preciliary vesicle transportation to the mother centriole during ciliogenesis. Nat Cell Biol. 2018; 20(2): 175-85.

PubMed Abstract | Publisher Full Text | Faculty Opinions Recommendation

22. Knödler A, Feng S, Zhang J, et al:: Coordination of Rab8 and Rab11 in primary ciliogenesis. Proc Natl Acad Sci U S A. 2010; 107(14): 6346-51. PubMed Abstract | Publisher Full Text | Free Full Text

23. Nachury MV, Loktev AV, Zhang Q, et al:: A core complex of BBS proteins cooperates with the GTPase Rab8 to promote ciliary membrane biogenesis. Cell. 2007; 129(6): 1201-13.

PubMed Abstract | Publisher Full Text | Faculty Opinions Recommendation

24. Cyoshimura Si, Egerer J, Fuchs E, et al:: Functional dissection of Rab GTPases involved in primary cilium formation. J Cell Biol. 2007; 178(3): 363-9. PubMed Abstract | Publisher Full Text | Free Full Text | Faculty Opinions Recommendation

25. Homma Y, Hiragi S, Fukuda M: Rab family of small GTPases: An updated view on their regulation and functions. FEBS J. 2021; 288(1): 36-55. PubMed Abstract | Publisher Full Text | Free Full Text | Faculty Opinions Recommendation

26. Walia V, Cuenca A, Vetter M, et al.: Akt Regulates a Rab11-Effector Switch Required for Ciliogenesis. Dev Cell. 2019; 50(2): 229-246.e7. PubMed Abstract | Publisher Full Text | Free Full Text

27. Asante D, Maccarthy-Morrogh L, Townley AK, et al:: A role for the Golgi matrix protein giantin in ciliogenesis through control of the localization of dynein-2. J Cell Sci. 2013; 126(Pt 22): 5189-97.

PubMed Abstract | Publisher Full Text | Free Full Text

28. Assis LHP, Silva-Junior RMP, Dolce LG, et al.: The molecular motor Myosin Va interacts with the cilia-centrosomal protein RPGRIP1L. Sci Rep. 2017; 7: 43692. PubMed Abstract | Publisher Full Text | Free Full Text

29. Morthorst SK, Christensen ST, Pedersen LB: Regulation of ciliary membrane protein trafficking and signalling by kinesin motor proteins. FEBS J.2018; 285(24): 4535-64.

PubMed Abstract | Publisher Full Text
30. Schrøder JM, Larsen J, Komarova Y, et al.: EB1 and EB3 promote cilia biogenesis by several centrosome-related mechanisms. J Cell Sci. 2011; 124(Pt 15): 2539-51.

PubMed Abstract | Publisher Full Text | Free Full Text

31. Mönnich M, Borgeskov L, Breslin L, et al.: CEP128 Localizes to the Subdistal Appendages of the Mother Centriole and Regulates TGF- $\beta$ /BMP Signaling at the Primary Cilium. Cell Rep. 2018; 22(10): 2584-92.

PubMed Abstract | Publisher Full Text | Faculty Opinions Recommendation

32. Schmidt KN, Kuhns S, Neuner A, et al.: Cep164 mediates vesicular docking to the mother centriole during early steps of ciliogenesis. J Cell Biol. 2012; 199(7): 1083-101.

PubMed Abstract | Publisher Full Text | Free Full Text

Faculty Opinions Recommendation

33. Cuenca A, Insinna $\mathrm{C}$, Zhao H, et al: The C7orf43/TRAPPC14 component links the TRAPPII complex to Rabin8 for preciliary vesicle tethering at the mother centriole during ciliogenesis. J Biol Chem. 2019; 294(42): 15418-34. PubMed Abstract | Publisher Full Text | Free Full Text

34. Chiba S, Amagai $Y$, Homma $Y$, et al: NDR2-mediated Rabin8 phosphorylation is crucial for ciliogenesis by switching binding specificity from phosphatidylserine to Sec15. EMBO J. 2013; 32(6): 874-85. PubMed Abstract | Publisher Full Text | Free Full Text

35. Graser S, Stierhof YD, Lavoie SB, et al: Cep164, a novel centriole appendage protein required for primary cilium formation. J Cell Biol. 2007; 179(2): 321-30. PubMed Abstract | Publisher Full Text | Free Full Text

36. Xu S, Liu Y, Meng Q, et al.: Rab34 small GTPase is required for Hedgehog signaling and an early step of ciliary vesicle formation in mouse. J Cell Sci. 2018; 131(21): jcs213710

PubMed Abstract | Publisher Full Text | Free Full Text |

Faculty Opinions Recommendation

37. Kuhns S, Seixas C, Pestana S, et al.: Rab35 controls cilium length, function and membrane composition. EMBO Rep. 2019; 20(10): e47625. PubMed Abstract | Publisher Full Text | Free Full Text | Faculty Opinions Recommendation

38. Fuller K, O'Connell JT, Gordon J, et al.: Rab23 regulates Nodal signaling in vertebrate left-right patterning independently of the Hedgehog pathway. Dev Biol. 2014; 391(2): 182-95.

PubMed Abstract | Publisher Full Text | Faculty Opinions Recommendation

39. Lim YS, Tang BL: A role for Rab23 in the trafficking of Kif17 to the primary cilium. J Cell Sci. 2015; 128(16): 2996-3008.

PubMed Abstract | Publisher Full Text

40. Onnis A, Finetti F, Patrussi L, et al.: The small GTPase Rab29 is a common regulator of immune synapse assembly and ciliogenesis. Cell Death Differ. 2015; 22(10): 1687-99.

PubMed Abstract | Publisher Full Text | Free Full Text

41. Sato T, Iwano T, Kunii M, et al:: Rab8a and Rab8b are essential for several apical transport pathways but insufficient for ciliogenesis. J Cell Sci. 2014 127(Pt 2): 422-31.

PubMed Abstract | Publisher Full Text | Free Full Text

42. Dhekne HS, Yanatori I, Gomez RC, et al:: A pathway for Parkinson's Disease LRRK2 kinase to block primary cilia and Sonic hedgehog signaling in the brain. eLife. 2018; 7: e40202.

PubMed Abstract | Publisher Full Text | Free Full Text |

Faculty Opinions Recommendation

43. Hattula K, Furuhjelm J, Arffman A, et al:: A Rab8-specific GDP/GTP exchange factor is involved in actin remodeling and polarized membrane transport. $\mathrm{Mol}$ Biol Cell. 2002; 13(9): 3268-80.

PubMed Abstract | Publisher Full Text | Free Full Text

44. Homma Y, Fukuda M: Rabin8 regulates neurite outgrowth in both GEF activitydependent and -independent manners. Mol Biol Cell. 2016; 27(3): 2107-18. PubMed Abstract | Publisher Full Text | Free Full Text

45. Insinna C, Lu Q, Teixeira I, et al.: Investigation of F-BAR domain PACSIN proteins uncovers membrane tubulation function in cilia assembly and transport. Nat Commun. 2019; 10(1): 428 .

PubMed Abstract | Publisher Full Text | Free Full Text |

Faculty Opinions Recommendation

46. Xie S, Farmer T, Naslavsky N, et al.: MICAL-L1 coordinates ciliogenesis by recruiting EHD1 to the primary cilium. J Cell Sci. 2019; 132(22): jcs233973. PubMed Abstract | Publisher Full Text | Free Full Text | Faculty Opinions Recommendation

47. Daumke O, Lundmark R, Vallis Y, et al:: Architectural and mechanistic insights into an EHD ATPase involved in membrane remodelling. Nature. 2007; 449(7164): 923-7.

PubMed Abstract | Publisher Full Text | Faculty Opinions Recommendation

48. McDonald NA, Gould KL: Linking up at the BAR: Oligomerization and F-BAR protein function. Cell Cycle. 2016; 15(15): 1977-85. PubMed Abstract | Publisher Full Text | Free Full Text

49. Naslavsky N, Caplan S: EHD proteins: key conductors of endocytic transport. 
Trends Cell Biol. 2011; 21(2): 122-31.

PubMed Abstract | Publisher Full Text | Free Full Text

50. Huang N, Zhang D, Li F, et al.: M-Phase Phosphoprotein 9 regulates ciliogenesis by modulating CP110-CEP97 complex localization at the mother centriole. Nat Commun. 2018; 9(1): 4511.

PubMed Abstract | Publisher Full Text | Free Full Text | Faculty Opinions Recommendation

51. C Bernatik O, Pejskova P, Vyslouzil D, et al.: Phosphorylation of multiple proteins involved in ciliogenesis by Tau Tubulin kinase 2. Mol Biol Cell. 2020; 31(10): 1032-46.

PubMed Abstract | Publisher Full Text | Free Full Text |

Faculty Opinions Recommendation

52. Nagai T, Mukoyama S, Kagiwada H, et al.: Cullin-3-KCTD10-mediated CEP97 degradation promotes primary cilium formation. J Cell Sci. 2018; 131(24): jcs219527.

PubMed Abstract | Publisher Full Text | Faculty Opinions Recommendation

53. Xu Q, Zhang Y, Wei Q, et al.: Phosphatidylinositol phosphate kinase PIPKI $\gamma$ and phosphatase INPP5E coordinate initiation of ciliogenesis. Nat Commun. 2016; 7: 10777 .

PubMed Abstract | Publisher Full Text | Free Full Text

54. D'Angelo G, Vicinanza M, Di Campli A, et al:: The multiple roles of Ptdlns(4)P -- not just the precursor of Ptdlns(4,5)P2. J Cell Sci. 2008; 121(Pt 12): 1955-63. PubMed Abstract | Publisher Full Text

55. Campa CC, Hirsch E: Rab11 and phosphoinositides: A synergy of signal transducers in the control of vesicular trafficking. Adv Biol Regul. 2017; 63: $132-9$.

PubMed Abstract | Publisher Full Text

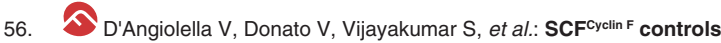
centrosome homeostasis and mitotic fidelity through CP110 degradation. Nature. 2010; 466(7302): 138-42

PubMed Abstract | Publisher Full Text | Free Full Text |

Faculty Opinions Recommendation

57. Al-Hakim AK, Bashkurov M, Gingras AC, et al.: Interaction proteomics identify NEURL4 and the HECT E3 ligase HERC2 as novel modulators of centrosome architecture. Mol Cell Proteomics. 2012; 11(6): M111.014233. PubMed Abstract | Publisher Full Text | Free Full Text

58. Loukil A, Tormanen $\mathrm{K}$, Sütterlin $\mathrm{C}$ : The daughter centriole controls ciliogenesis by regulating Neurl-4 localization at the centrosome. J Cell Biol. 2017; 216(5): 1287-300.

PubMed Abstract | Publisher Full Text | Free Full Text

59. Burke MC, Li FQ, Cyge B, et al.: Chibby promotes ciliary vesicle formation and basal body docking during airway cell differentiation. J Cell Biol. 2014; 207(1) 123-37.

PubMed Abstract | Publisher Full Text | Free Full Text

60. Kim J, Krishnaswami SR, Gleeson JG: CEP290 interacts with the centriolar satellite component PCM-1 and is required for Rab8 localization to the primary cilium. Hum Mol Genet. 2008; 17(23): 3796-805.

PubMed Abstract | Publisher Full Text | Free Full Text

61. Muñoz-Estrada J, Ferland RJ: Ahi1 promotes Arl13b ciliary recruitment, regulates Arl13b stability and is required for normal cell migration. J Cell Sci. 2019; 132(17): jcs230680.

PubMed Abstract | Publisher Full Text | Free Full Text

62. Lapart JA, Gottardo M, Cortier E, et al: Dzip1 and Fam92 form a ciliary transition zone complex with cell type specific roles in Drosophila. eLife. 2019; 8: e49307. PubMed Abstract | Publisher Full Text | Free Full Text

63. Lu H, Galeano MCR, Ott E, et al:: Mutations in DZIP1L, which encodes a ciliarytransition-zone protein, cause autosomal recessive polycystic kidney disease. Nat Genet. 2017; 49(7): 1025-34.

PubMed Abstract | Publisher Full Text | Free Full Text

64. Wang C, Li J, Takemaru KI, et al:: Centrosomal protein Dzip1I binds Cby, promotes ciliary bud formation, and acts redundantly with Bromi to regulate ciliogenesis in the mouse. Development. 2018; 145(6): dev164236. PubMed Abstract | Publisher Full Text | Free Full Text | Faculty Opinions Recommendation

65. Kobayashi T, Kim S, Lin YC, et al:: The CP110-interacting proteins Talpid3 and Cep290 play overlapping and distinct roles in cilia assembly. J Cell Biol. 2014 204(2): 215-29.

PubMed Abstract | Publisher Full Text | Free Full Text

66. Shimada H, Lu Q, Insinna-Kettenhofen C, et al:: In Vitro Modeling Using Ciliopathy-Patient-Derived Cells Reveals Distinct Cilia Dysfunctions Caused by CEP290 Mutations. Cell Rep. 2017; 20(2): 384-96. PubMed Abstract | Publisher Full Text | Free Full Text

67. Besharse JC, Forestner DM, Defoe DM: Membrane assembly in retinal photoreceptors. III. Distinct membrane domains of the connecting cilium of developing rods. J Neurosci. 1985; 5(4): 1035-48. PubMed Abstract | Publisher Full Text | Free Full Text

68. Gilula NB, Satir P: The ciliary necklace. A ciliary membrane specialization. J Cell Biol. 1972; 53(2): 494-509.

PubMed Abstract | Publisher Full Text | Free Full Text
69. Gogendeau D, Lemullois M, Le Borgne P, et al:: MKS-NPHP module proteins control ciliary shedding at the transition zone. PLOS Biol. 2020; 18(3): e3000640.

PubMed Abstract | Publisher Full Text | Free Full Text |

Faculty Opinions Recommendation

70. Valente EM, Logan CV, Mougou-Zerelli S, et al.: Mutations in TMEM216 perturb ciliogenesis and cause Joubert, Meckel and related syndromes. Nat Genet. 2010; 42(7): 619-25.

PubMed Abstract | Publisher Full Text | Free Full Text

71. Garcia-Gonzalo FR, Corbit KC, Sirerol-Piquer MS, et al:: A transition zone complex regulates mammalian ciliogenesis and ciliary membrane composition. Nat Genet. 2011; 43(8): 776-84.

PubMed Abstract | Publisher Full Text | Free Full Text |

Faculty Opinions Recommendation

72. Huang L, Szymanska K, Jensen VL, et al.: TMEM237 is mutated in individuals with a Joubert syndrome related disorder and expands the role of the TMEM family at the ciliary transition zone. Am J Hum Genet. 2011; 89(6): 713-30. PubMed Abstract | Publisher Full Text | Free Full Text

73. Roberson EC, Dowdle WE, Ozanturk A, et al.: TMEM231, mutated in orofaciodigital and Meckel syndromes, organizes the ciliary transition zone. $J$ Cell Biol. 2015; 209(1): 129-42.

PubMed Abstract | Publisher Full Text | Free Full Text

74. Li FQ, Chen X, Fisher C, et al:: BAR Domain-Containing FAM92 Proteins Interact with Chibby1 To Facilitate Ciliogenesis. Mol Cell Biol. 2016; 36(21): 2668-80. PubMed Abstract | Publisher Full Text | Free Full Text

75. Garcia G, Raleigh DR, Reiter JF: How the Ciliary Membrane Is Organized Inside-Out to Communicate Outside-In. Curr Biol. 2018; 28(8): R421-R434. PubMed Abstract | Publisher Full Text | Free Full Text | Faculty Opinions Recommendation

76. Silverman MA, Leroux MR: Intraflagellar transport and the generation of dynamic, structurally and functionally diverse cilia. Trends Cell Biol. 2009; 19(7): 306-16.

PubMed Abstract | Publisher Full Text

77. Kim J, Lee JE, Heynen-Genel S: Functional genomic screen for modulators of ciliogenesis and cilium length. Nature. 2010; 464(7291): 1048-51. PubMed Abstract | Publisher Full Text | Free Full Text | Faculty Opinions Recommendation

78. Agbu SO, Liang Y, Liu A, et al:: The small GTPase RSG1 controls a final step in primary cilia initiation. J Cell Biol. 2018; 217(1): 413-27. PubMed Abstract | Publisher Full Text | Free Full Text | Faculty Opinions Recommendation

79. Taschner M, Lorentzen E: The Intraflagellar Transport Machinery. Cold Spring Harb Perspect Biol. 2016; 8(10): a028092.

PubMed Abstract | Publisher Full Text | Free Full Text

80. Ishikawa H, Marshall WF: Intraflagellar Transport and Ciliary Dynamics. Cold Spring Harb Perspect Biol. 2017; 9(3): a021998. PubMed Abstract | Publisher Full Text | Free Full Text

81. Wood CR, Rosenbaum JL: Proteins of the ciliary axoneme are found on cytoplasmic membrane vesicles during growth of cilia. Curr Biol. 2014; 24(10): 1114-20.

PubMed Abstract | Publisher Full Text | Free Full Text | Faculty Opinions Recommendation

82. Wang $\mathrm{Q}$, Taschner M, Ganzinger KA, et al:: Membrane association and remodeling by intraflagellar transport protein IFT172. Nat Commun. 2018; 9(1): 4684.

PubMed Abstract | Publisher Full Text | Free Full Text

83. Omori $\mathrm{Y}$, Zhao $\mathrm{C}$, Saras A, et al:: Elipsa is an early determinant of ciliogenesis that links the IFT particle to membrane-associated small GTPase Rab8. Nat Cell Biol. 2008; 10(4): 437-44.

PubMed Abstract | Publisher Full Text

84. Finetti F, Patrussi L, Galgano D, et al.: The small GTPase Rab8 interacts with VAMP-3 to regulate the delivery of recycling T-cell receptors to the immune synapse. J Cell Sci. 2015; 128(14): 2541-52.

PubMed Abstract | Publisher Full Text | Free Full Text

85. Finetti F, Patrussi L, Masi G, et al.: Specific recycling receptors are targeted to the immune synapse by the intraflagellar transport system. J Cell Sci. 2014; 127(Pt 9): 1924-37.

PubMed Abstract | Publisher Full Text | Free Full Text

86. Zuo X, Guo W, Lipschutz JH: The exocyst protein Sec10 is necessary for primary ciliogenesis and cystogenesis in vitro. Mol Biol Cell. 2009; 20(10): 2522-9.

PubMed Abstract | Publisher Full Text | Free Full Text |

Faculty Opinions Recommendation

87. Fogelgren B, Lin SY, Zuo X, et al:: The exocyst protein Sec10 interacts with Polycystin-2 and knockdown causes PKD-phenotypes. PLoS Genet. 2011; 7(4): e1001361.

PubMed Abstract | Publisher Full Text | Free Full Text 
88. Nozaki S, Katoh $\mathrm{Y}$, Terada M, et al.: Regulation of ciliary retrograde protein trafficking by the Joubert syndrome proteins ARL13B and INPP5E. J Cell Sci. 2017; 130(3): 563-76. PubMed Abstract | Publisher Full Text

89. Seixas C, Choi SY, Polgar N, et al.: Arl13b and the exocyst interact synergistically in ciliogenesis. Mol Biol Cell. 2016; 27(2): 308-20. PubMed Abstract | Publisher Full Text | Free Full Text

90. Caspary T, Larkins CE, Anderson KV: The graded response to Sonic Hedgehog depends on cilia architecture. Dev Cell. 2007; 12(5): 767-78. PubMed Abstract | Publisher Full Text | Faculty Opinions Recommendation

91. Gerondopoulos A, Strutt H, Stevenson NL, et al:: Planar Cell Polarity Effector Proteins Inturned and Fuzzy Form a Rab23 GEF Complex. Curr Biol. 2019; 29(19): 3323-3330.e8.

PubMed Abstract | Publisher Full Text | Free Full Text |

Faculty Opinions Recommendation

92. Coriyama M, Lee C, Taylor SP, et al.: The ciliopathy-associated CPLANE proteins direct basal body recruitment of intraflagellar transport machinery. Nat Genet. 2016; 48(6): 648-56.

PubMed Abstract | Publisher Full Text | Free Full Text | Faculty Opinions Recommendation

93. Ko HW, Norman RX, Tran J, et al.: Broad-minded links cell cycle-related kinase to cilia assembly and hedgehog signal transduction. Dev Cell. 2010 18(2): 237-47.

PubMed Abstract | Publisher Full Text | Free Full Text |

Faculty Opinions Recommendation

94. Diener DR, Lupetti P, Rosenbaum JL: Proteomic analysis of isolated ciliary transition zones reveals the presence of ESCRT proteins. Curr Biol. 2015; 25(3): $379-84$.

PubMed Abstract | Publisher Full Text | Free Full Text

95. Iaconis D, Crina C, Brillante S, et al.: The HOPS complex subunit VPS39 controls ciliogenesis through autophagy. Hum Mol Genet. 2020; 29(6): 1018-29. PubMed Abstract | Publisher Full Text | Free Full Text | Faculty Opinions Recommendation

96. Monis WJ, Faundez V, Pazour GJ: BLOC-1 is required for selective membrane protein trafficking from endosomes to primary cilia. J Cell Biol. 2017; 216(7): 2131-50.

PubMed Abstract | Publisher Full Text | Free Full Text

97. Cantagrel V, Silhavy JL, Bielas SL, et al:: Mutations in the cilia gene ARL13B lead to the classical form of Joubert syndrome. Am J Hum Genet. 2008; 83(2): 170-9.

PubMed Abstract | Publisher Full Text | Free Full Text |

Faculty Opinions Recommendation

98. Jenkins D, Seelow D, Jehee FS, et al.: RAB23 mutations in Carpenter syndrome imply an unexpected role for hedgehog signaling in cranial-suture development and obesity. Am J Hum Genet. 2007; 80(6): 1162-70. PubMed Abstract | Publisher Full Text | Free Full Text

99. Dixon-Salazar TJ, Silhavy JL, Udpa N, et al.: Exome sequencing can improve diagnosis and alter patient management. Sci Transl Med. 2012; 4(138): 138ra78. PubMed Abstract | Publisher Full Text | Free Full Text

100. Shaheen R, Faqeih E, Alshammari MJ, et al:: Genomic analysis of Meckel-Gruber syndrome in Arabs reveals marked genetic heterogeneity and novel candidate genes. Eur J Hum Genet. 2013; 21(7): 762-8.

PubMed Abstract | Publisher Full Text | Free Full Text 